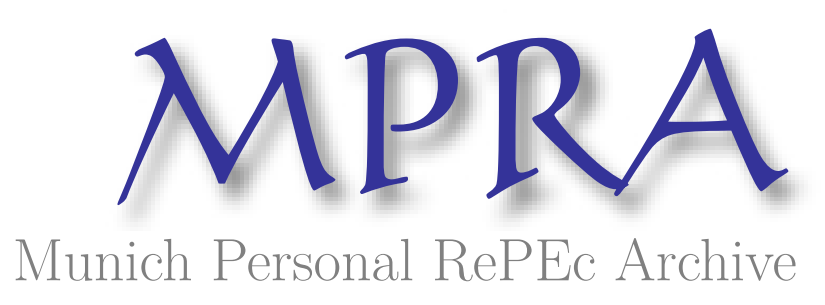

\title{
Will China Avoid the Middle-Income Trap?
}

Zhou, Haiwen

13 November 2017

Online at https://mpra.ub.uni-muenchen.de/82688/

MPRA Paper No. 82688, posted 18 Nov 2017 09:31 UTC 


\title{
Will China Avoid the Middle-Income Trap?
}

\author{
Haiwen Zhou
}

\begin{abstract}
This paper employs a historical approach to address whether a country can avoid the middle-income trap. The development of the manufacturing sector and technological capacities are important for a country to avoid the middle-income trap. South Korea avoided the middleincome trap through developing the manufacturing sector. Argentina became a middle-income country by exporting agricultural goods and fell victim to the trap. The distribution of political power between state and society affect a country's capacity to develop technological capabilities. The concentration of power in the government in China is affected by historical factors. With the provision of equal opportunities to all citizens, China will avoid the middle-income trap with her building-up of technological and innovative capacities. The reasoning here can also be used to understand development experiences of other countries.
\end{abstract}

Keywords: Middle-income trap, economy of China, political economy, technological capability, economic development

\section{JEL Classification Numbers: O14, O30, O53, P16}

\section{Introduction}

A middle-income country may not be able to compete with a low-income country in laborintensive industries: compared with the wage rate in a low-income country, the wage rate in the middle-income country is too high. The middle-income country may not be able to compete with a high-income country in technology intensive industries: compared with the research and development capacities in a high-income country, the research and development capacities in this middle-income country are too low (World Bank, 2010, p. 27). A country may continue to have a middle-income status for an extended period without being able to "graduate" to achieve a highincome status. This is the so called "middle income trap."

For a country currently with a middle level of income, whether this country will be able to avoid the middle-income trap is an interesting issue. One example is China. After more than thirty years of high growth, China is an upper middle-income country (according to the World Bank, in 2016 China's per capita GDP is 8,123.2 dollars). Will China avoid the middle-income trap? This is an interesting issue to policy makers and citizens in China. China's process of growth is also the process of integration into the world economy. With a population size of more than 1.3 billion, the scale of China's integration into the world is unprecedented in world history. Thus, whether China will avoid the middle-income trap is also an interesting issue to people outside China. 
The World Bank publishes data for the critical level of income that a country is classified as a high-income country. For example, for the 2017-2018 fiscal year, a high-income country is one with per capita Gross National Income higher than $\$ 12,235$ dollars. A country with a highincome status may be viewed as having avoided the middle-income trap. While this classification is useful for some purposes, here we are not very interested in checking whether a country has passed the minimum level of income to be classified as a high-income country. To us, if a country has a per capita income higher than a critical level, it does not necessarily mean that the economy is based on solid foundations and citizens in this country can relax for a while. A small economy may be able to sustain an elevated level of per capita income by relying on the service sector. For example, gambling is the most important sector in Macau Special Administrative Region of China and Macau has a high-income status. However, for a large country, this reliance on the service sector is not sustainable. The service sector needs to be based on the manufacturing sector and the ability to adopt and develop innovative technologies is essential for the manufacturing sector of a large country to grow and thus to avoid the middle-income trap.

In this paper, we argue that the establishment of technological capabilities in the manufacturing sector indicates that a large economy has avoided the middle-income trap. ${ }^{1}$ With land reform removed the possibility of large landowners opposing industrialization, South Korea avoids the middle-income trap through the development of the manufacturing sector and technological capacities. With a deeply divided society, Argentina became a middle-income country through exporting agricultural goods. As argued in Section 3, Argentina experienced deindustrialization at her "golden age" of development. Argentina firms are usually not capable in unbundling foreign technologies. It is not strange that Argentina is a victim of the middle-income trap.

With land reform in the 1950s, oppositions of industrialization in China by land owners became impossible. With capital accumulation through huge sacrifices of citizens before 1978, China became a middle-income country through the development of the manufacturing sector after 1978. Currently, China has high income inequality. If income inequality can be reduced through providing open access of resources and opportunities to citizens, China will avoid the middleincome trap with the building up of innovative capacities.

\footnotetext{
${ }^{1}$ Malechi (1991, Chap. 4) has a detailed discussion of the importance of technological capability in economic development.
} 
In his stimulating book, Olson (1982) has argued that the development of interests groups in a stable society can harm economic growth. The argument here is consistent with his view in the sense that interest groups such as large landowners could harm the development of the manufacturing sector in various countries. That is, governments could be "weak" and captured by interests groups and could not implement policies for industrialization (Huntington, 1968; Migdal, 1988).

While the concept of middle-income trap may be controversial, the literature on the middleincome trap is growing rapidly (Cai, 2012). Econometric analysis of the trap on various countries is conducted by Aiyar et al. (2013). This paper is directly related to studies on China's avoidance of the middle-income trap such as Lee and $\mathrm{Li}$ (2014) and $\mathrm{Wu}$ (2014). Like those two studies, this paper argues that technological improvements would be important for China to avoid the middleincome trp. Complementary to econometric studies, this paper employs a historical approach in the study of the middle-income trap and explores political economy factors to explain why countries differ in their capacities in developing technological competences. Scholars such as Lin (2017) have also emphasized that industry upgrading, building of infrastructure, and financial development would be important for China to avoid the middle-income trap. Those kinds of views are consistent with the argument here that technological capability is essential for avoiding the middle-income trap: industry upgrading depends on technological progress, developing technological capabilities and infrastructure are complementary, and financial development will reduce the costs of technology adoption of manufacturing firms.

The plan of the paper is as follows. Section 2 establishes the importance of technological capacities in avoiding the middle-income trap. Section 3 presents South Korea as a successful example and Argentina as an unsuccessful example of avoiding the middle-income trap. Section 4 illustrates China's development of the manufacturing sector and technological capabilities in the last four decades. Section 5 discusses whether China will avoid the middle-income trap. Section 6 concludes.

\section{The importance of technological capability in the manufacturing sector}

The problems faced by low income countries and middle-income countries are different. A low-income country may have customs and traditions such as the caste system limiting its capacity to consolidate resources to develop the economy (Myrdal, 1968). A country may have a 
low income for various reasons, such as from civil wars. While developing technological capabilities is essential for a middle-income country to grow, it may not be essential for a lowincome country.

Technological improvement is essential to avoid the middle-income trap. ${ }^{2}$ The importance of developing technological capabilities can be understood by placing the issue of middle-income trap into the broad background of industrialization. Currently developed countries can enjoy much higher levels of income than two hundred years ago. Roughly speaking, a prominent level of per capita income is associated with a prominent level of labor productivity, which can be achieved through better technologies. This connection between technological capability and wage rate is also reflected in international trade theory. In the Heckscher-Ohlin model, the opening of international trade leads to the equalization of wage rates between countries if they have access to the same technologies. In the Ricardian model, a country with better technologies (absolute advantage) will have a higher wage rate even after the opening of international trade.

The importance of technological capability can be illustrated through three examples. First, we look at a comparative study of the textile industry in Japan and India. At the beginning of the $20^{\text {th }}$ century, both countries imported textile machines from Britain, frequently from the same British companies. Why was Japan successful in developing its textile industry while India was not? There are numerous factors leading to the differences in performance between the two countries. One is that while the Japanese textile industry benefited from tariff protections, India at that time was a colony of Britain and did not have control over its tariff rates (Beckert, 2014). More importantly, Japan had the technological capabilities to modify imported machines, such as using wood instead of steel to produce machines. Even though products made from wooden machines were of lower qualities than products made from steel machines, the prices of goods made from wooden machines were much cheaper than those made from steel machines. In addition, wooden machines were not as heavy as steel machines, and this contributed to the hiring of female workers which were in abundant supplies in Japan at that time. The low-priced textile goods of Japan became internationally competitive and gradually occupied markets in China and even India. Exports of textile goods created many employment opportunities and helped the industrialization of Japan. In contrast, India did not have technological capabilities to modify

\footnotetext{
2 At the micro level, Ju, Fung, and Mano (2013) have studied how a firm's performance is affected by technological capabilities, and Gao et al. (2013) have shown that a firm's competitiveness increases with its technological capacity.
} 
imported machines and the development of the textile industry lagged (Otsuka, Ranis, and Saxonhouse, 1988).

Second, we look at a comparison between Brazil and Japan. The eruption of World War I decreased exports of manufactured goods from Europe to Asia and Latin America. While this decrease in competition from Europe helped Japan in the development of industries producing capital goods, Brazil did not gain much. During World War I, without the competition of European goods, the production of consumer goods in Japan increased significantly. To provide machines for sectors producing consumer goods, industries producing capital goods developed rapidly in Japan. With reduced imports and increases in revenues from providing shipping service, trade deficits of Japan turned into trade surpluses (Lockwood, 1968). Without the competition of European goods, Brazilian production of consumer goods also increased. However, without related supporting industries, Brazil could not develop the production of capital goods and relied on overruns of existing imported machines. After the War, Brazil had to import many machines for replacement (Baer, 2001). Overall, sectors producing capital goods in Brazil did not gain much from the temporary decrease in competition caused by World War I.

Third, we look at a comparison between Brazil and South Korea in the automobile industry. The Brazil government used high tariffs for import substitution in the 1950s. Under strong US pressure, the Brazilian government had to allow foreign firms to invest. Without limit on equity ownership, foreign firms established wholly owned subsidies in Brazil. Thus, Volkswagen, Ford, and General Motors had combined market share of more than $90 \%$ in the 1970 s and crowded out local firms. Even local parts producers were crowded out and the Brazilian auto industry became dominated by foreign firms after the Brazilian government pushed for export in the 1980s (Chu, 2011). The South Korean government used export records as a performance standard, and adopted a policy of promoting indigenous technological development in 1973. With the development of indigenous technological capabilities, South Korea's automobile industry is much more successful than that of Brazil.

For systematic empirical evidence on the relationship between technological capabilities and the middle-income trap, Eichengreen, Park, and Shin (2014) have found that countries with high-technology products accounts for a relatively large share of exports are less likely to have a growth slowdown, showing the importance of moving up the technology ladder to avoid the 
middle-income trap. A country's ability to export high-technology products and to move up the technology ladder depends on technological capabilities.

For an independent country, the importance of developing the manufacturing sector is emphasized in List (1856). In his words, agriculture and manufacture to a country is like two arms to an individual. If a country does not develop manufacturing, then it is like a person loses one arm. While the manufacturing sector is associated with increasing returns and spillovers, the agricultural sector exhibits decreasing returns if more and more labor is applied on a fixed amount of land. Developing technological capabilities is associated with developing the manufacturing sector.

Improving technological capabilities is dynamic in nature. How may a country keep on improving technological capabilities $?^{3}$ For a country that is not at the technological frontiers, improving technologies depends on the ability to adopt technologies from advanced countries. For a country on the technological frontiers, the ability to develop indigenous technologies is important. The process of technology adoption and industrialization can be understood as follows. To improve technological capability, machines need to be imported because technologies are embodied in machines. Initially, a developing economy exports agricultural goods to earn foreign exchanges to import machines. Then, this economy moves a little higher in the ladder to export labor-intensive manufactured goods, such as textile goods. With more capital accumulation, the cost of capital decreases and this economy may be able to export more capital-intensive goods, and so on (Lin, 2012).

If the development of technological capacity in the manufacturing sector is important and well-recognized by scholars and policy makers, why were some countries able to improve technological capabilities and avoid the middle-income trap while some others could not? For a country in late development, the government needs to coordinate the development of the manufacturing sector and technological capacities. ${ }^{4}$ One important thing is that the process of technological development could cause significant losses to large segments of the economy. For a deeply divided society like Argentina, religions groups, labor unions, and multinational firms are very powerful, the government is weak and does not have the capacity to coordinate

\footnotetext{
${ }^{3}$ Chang (2003) and Beckert (2014) have illustrated policies used by countries such as Britain, German, and Japan to achieve industrialization. Policies used by Britain include ensuring markets through erecting tariffs and the prohibition of exporting raw materials.

${ }^{4}$ Initially the government, then banks played important roles in the industrialization of German (Trebilcock, 1981).
} 
industrialization. For example, multination firms in Argentina lobbied against Argentina's indigenous computer program by claiming that the program relied on protection and was not efficient (Adler, 1987). For a relatively homogenous society like South Korea, land reform removed powerful landlords opposing industrialization. In the language of Huntington (1968) and Migdal (1988), the South Korea government was "strong" and society was "weak". Thus, the government is strong to coordinate industrialization. Similarly, Black et al. (1975) have argued that one reason for the success of promoting education in Japan and Russia is that there is no religious group capable of opposing the government, and influences of labor unions in Japan and Russia were limited. In Japan, labor unions are not organized by industry, but are organized by companies. This makes the interests of companies and labor unions more likely to be aligned, and helped Japan's industrialization.

\section{Development experiences of countries}

In this section, we present South Korea as a successful example of avoiding the middleincome trap and Argentina as a not so successful one.

\subsection{The successful story of South Korea}

In terms of area and population size, South Korea is the largest among "the four tigers". Since we are mainly interested in how a large economy avoids the middle-income trap, we focus on the development experience of South Korea.

Under President Rhee Syngman, corruption was rampant in South Korea. Feeling frustrated, President Park Chung Hee came to power in 1961 after a military coup and he tried to promote the industrialization of South Korea. The government took many measures to promote exports to earn foreign exchanges to import machines. For example, President Park frequently attended meetings in which leaders from top South Korean companies reported their export performance (Wade, 2004). Companies with deficient performance may get punished. Promoting export did not mean that South Korea engaged in free trade. To reduce demand for foreign exchanges, imports were controlled through licenses and quotas and only necessary items could be imported. Also, to save foreign exchanges, citizens in South Korea were not allowed to travel freely to foreign countries. 
To improve technological capabilities, South Korea imported many foreign technologies. In the 1960s, South Korea mainly imported technologies from Japan. In the 1980s, South Korea imported technologies from the United States. Korean firms could unbundle elements of imported technological packages so that they did not waste money on unnecessary parts in such packages (Rhee, Ross-Larson, and Pursell, 1984, chap. 4). Foreign direct investment (FDI) played limited roles in South Korea development. Instead, South Korea relied on foreign borrowing.

Because heavy and chemical industries such as the steel industry provide inputs to many industries and are important in developing the technological capabilities of a country, President Park was interested in developing those industries for South Korea. To channel funds to targeted industries, President Park nationalized major banks. Chaebols invested in strategic industries received favored loans from state-owned banks with low interest rates. When President Park tried to develop Pohang Iron and Steel Company (POSCO) in the 1970s, he could not get loan from the World Bank. Under the influence of the United States government, the World Bank declined the loan request by arguing that there were already enough supplies of steel in the world. South Korea also could not get loan from the Asian Development Bank. Instead, with war repatriates, POSCO got help from Japanese steel companies who trained South Korea workers. POSCO also got subsidies from the South Korean government through low-priced electricity. Because the wage rate in South Korea was much lower than that in Japan, the company was profitable even though its labor productivity was much lower than that in Japan when POSCO started operation. Productivity differences between South Korea and Japan workers decreased over time, and eventually POSCO became very efficient even as a state-owned enterprise. The success of POSCO generated benefits for other industries in South Korea, such as the shipbuilding industry. Based on imported technologies from Japan and Europe, South Korea develops a very competitive shipbuilding industry (Amsden, 1989).

Table 1 shows that the manufacturing sector produces an increasing percentage of value added and exporting manufactured goods became more important during South Korea's period of take-off. 
Table 1: Korea's manufacturing sector

\begin{tabular}{|l|l|l|l|}
\hline Year & 1953 & 1957 & 1972 \\
\hline Percentage of total value added & 6 & 9 & 25 \\
\hline Percentage of total exports & 2.3 & 18.2 & 71.2 \\
\hline
\end{tabular}

Source: Hong (1980, pp. 343-344).

Why was it possible for President Park to implement his policies? South Korea conducted land reform after World War II. ${ }^{5}$ Land reform led to diverse ownerships of land in South Korea (Deyo, 1989). ${ }^{6}$ It helped South Korea to achieve an equal income distribution during the process of industrialization. More importantly, it eliminated landlords as a political opposition force in economic development. Thus, the South Korea government could implement its policies. While a specific group may lose from a specific government policy in the short run, economic development resulted if the same specific group did not always lose in the long run.

The takeoff process of South Korea was not painless. ${ }^{7}$ First, this process may not be smooth for firms. The textile industry was the leading sector for South Korea in the 1960s and earned the needed foreign exchanges. However, most of the firms succeeded in exporting textiles failed in industry upgrading (Amsden, 1989). Second, citizens suffered during the process. Peasants were squeezed through low prices of agricultural goods and industrial accidents in South Korea were severe. Labor unions in South Korea were suppressed and individuals active in organizing labor unions could be charged with engaging in communism and jailed. The growth rates of wages were lower than these of labor productivities. Hourly compensation for manufacturing workers in South Korea in 1986 was still lower than that in Brazil and Mexico (Deyo, 1989, p. 91). Low wages helped capital accumulation, but were not beneficial to workers. Third, pollutions in South Korea

\footnotetext{
${ }^{5}$ While land reform was frequently proposed in India, India has not enforced a land reform successfully. With differences in languages, religions, and castes, the distribution of political power in India is diverse (Myrdal, 1968). It is not strange that Indira Gandhi tried to use emergence control so that she could have more concentrated power to implement her desired policies. After the split of the National Congress, India politics became even more fragmented, with hundreds of parties, and many of them are local ones (Frankel, 2005).

${ }^{6}$ The development pattern of South Korea was influenced by that of Japan. Japan also had land reform prior to the process of taking off (Yoshida, 1967). Black et al. (1975) have illustrated the importance of a strong government in the industrialization of Japan.

${ }^{7}$ The industrialization process in Japan was also painful. The Japanese government did not do much to improve the conditions of workers during the process of Japan's economic takeoff (Lockwood, 1968).
} 
became worse. When social conflicts intensified, President Park was assassinated by one of his key subordinates in 1979.

\subsection{Argentina in the middle-income trap}

It is frequently stated that Argentina was one of the richest countries in the world at the beginning of the $21^{\text {st }}$ century. Today Argentina's per capita GDP is about the same as the world average. Even during the days that Argentina was rich, the wealth was built on the export of agricultural goods to Europe and the United States, not on the export of manufactured goods. In 1913, Argentina's industrial output per capita was about $50 \%$ of the Australian level, $20 \%$ of the Canadian level, and less than $10 \%$ of the US level (Francis, 2014, p. 172). The textile industry was the key industry in Britain's Industrial Revolution (Beckert, 2014). While this industry currently is not in the technology frontiers, it is still a starting point for countries to accumulate their technological capabilities and countries such as Japan and South Korea had impressive performance in exporting textile goods during their takeoff periods. Table 2 shows that Argentina had a declining textile industry at the end of the $19^{\text {th }}$ century. Soaring prices of agricultural goods led to booms in exporting agricultural goods and Argentina had deindustrialization during the glory days (Francis, 2014). Argentina is not a "melting pot" for waves of immigrants (Brown, 2011). As a deeply divided society, the government does not have the capacity to establish strong technological capabilities to sustain growth. Thus, it's not strange that Argentina has not moved beyond the middle-income trap.

Table 2: Argentina's textile industry

\begin{tabular}{|l|l|l|}
\hline Year & Total number of workers & Per cent of total occupations \\
\hline 1869 & 94,882 & 11.1 \\
\hline 1895 & 39,725 & 2.4 \\
\hline 1914 & 30,980 & 1.0 \\
\hline
\end{tabular}

Source: Francis (2014, p. 169).

With abundant endowment of land, Argentina has a long tradition of exporting agricultural goods since colonial times. Large landlords opposed industrialization because tariffs needed to protect the manufacturing sector would increase the costs of imports. Land owners have argued 
that industrial sectors are "artificial" and developing the manufacturing sector will be against the comparative advantage of Argentina. In the $19^{\text {th }}$ century, the Argentinean government did not take systematic measures to push for industrialization.

Worrying about that the terms of trade from exporting agricultural goods may decrease over time, there are arguments supporting industrialization. Argentina in the 1930s adopted import substitution and used tariffs to support various industries. Influenced by the rise of Nazi in Europe, many military officers in Argentina thought that military power was important for a country and military power depended on a strong manufacturing sector (Lewis, 1990). Believing that civilian governments did not have enough implementation capacities to achieve industrialization, the military moved to the front stage to handle economic development directly. While the combination of military power with the civilian government increased the degree of power concentration, the government was still not strong enough to succeed in industrialization. ${ }^{8}$ As we have discussed in the case of South Korea, the process of industrialization may not be smooth. With a tradition of democracy, the tight measures taken by the military led to strong oppositions from other social groups, such as students and religious leaders. The military could not establish technological capabilities in a brief period. Firms could not unbundle foreign technologies, which are frequently viewed as black boxes in Latin America (Adler, 1987). The military juntas retreated when the problems of governance become too much for them (Huntington, 1968, p. 228). When soldiers returned to the barrack, civilian government took over power. After experiencing difficulties in the promotion of exporting manufacturing goods, opinions opposing import substitution could become popular. As a result, politicians reversed policies promoting export of manufactured goods, such as removing tariff protections. Since the fundamental problem of establishing technological capabilities is still not resolved, liberalization becomes unpopular after a while. The argument for industrialization will appear again and a new round of policy changes will begin. Because the stakes involved are high, political competition is fierce in a deeply divided society. In Argentina, there were frequent policy reversals. ${ }^{9}$ Argentina is an example of the frequent switches of military and civilian governments in Latin America.

\footnotetext{
${ }^{8}$ There were differences between military regimes in Latin America and East Asia. In Latin America such as Argentina, frequently it was a group of generals formed the military government. In East Asia such as South Korea and Taiwan province, it was one general or one family dominated the authoritarian regime.

${ }^{9}$ One example of this policy reversal is the relationship between central government and local governments. Since Argentina's independence, there were conflicts between federalist and individuals arguing for a stronger central government (Rock, 1985).
} 
Power distribution in Latin America is affected by historical factors (Brown, 2011) ${ }^{10}$ In Latin America, power is dispersed among the government, the Catholic Church, labor unions, multinational firms, and other sources. ${ }^{11}$ Thus, the government may not be strong enough to implement its policies. While politicians are interested in both long-run economic development and winning elections, the need to win elections is more immediate. Thus, measures taken by political parties to win elections could reduce the chance of economic development in the long run. To win elections, parties tried many ways to please voters. Sometimes, to make rewarding political supporters easier, parties did not want to establish minimum standards for government officials, such as requiring that officials should be able to read (Geddes, 1994). ${ }^{12}$ To reward political supporters, parties put them into state-owned enterprises and this led to overstaff in state-owned enterprises (Brown, 2011). To subsidize consumption, the prices of state-owned enterprises were set too low and thus state-owned enterprises were not profitable. While losing money, state-owned enterprises might not be closed to keep hiring political supporters. To fund subsidies to moneylosing state-owned enterprises, government may increase revenue by increasing taxes. However, measures to increase taxes would not be welcomed by voters. In Latin America, tax collections are loose and tax evasions are widespread. Without enough revenues, governments relied on domestic and foreign borrowing and printing money. Hyper-inflations and foreign debt crises are symptoms of lacking disciplines for some countries in Latin America. Without a stable macroeconomic environment, it would be difficult for the manufacturing sector to grow and prosper.

\footnotetext{
${ }^{10}$ The Catholic Church is an important player in Latin America politics. Historically, the process of colonization of Europeans in Latin America was also the process of the spread of the Catholic Church (Miller, 1985). Frequently, the Church was the largest land owner in a country and could own one third or an even higher percentage of the total amount of land in a country and the Church may not pay taxes. As seen from European history, the Church could be a powerful challenger to the secular government. While the power of secular government may last for only few years or even shorter, religion power can last much longer and thus can be more powerful than the government. When the government tried to redistribute land from the Church to peasants in Mexico, the Church threatened to excommunicate the peasants participating in the government's program. The Church may play the role of protectors for weak peasants and peasants were afraid of being isolated in communities. Thus, peasants might not participate in land reform sponsored by the government (Vernon, 1963).

${ }^{11}$ There are interactions among different political groups. For example, the Church may support labor unions against government policies.

${ }_{12}$ Measures taken to win votes may decrease economic efficiencies. For example, Frankel (2005) had argued that Indira Gandhi's nationalization of banks was for election purpose, rather than for economic reasons. She shows that local politicians in India promised free electricity for peasants to win elections. This led to huge waste of scarce resources and the cost of this project is about the same size as the annual education budget of India.
} 
Juan Peron's rule can be used to illustrate how economic decisions are affected by political considerations in Argentina. During World War II, Argentina accumulated several billions of foreign reserves by exporting agricultural goods to Europe. Peron government used these foreign reserves to purchase foreign owned infrastructure in Argentina, such as railways and airports. While this kind of purchase had propaganda value by arguing that Argentina was not controlled by foreign capital anymore, it did not increase the amount of productive capital. It has been argued that the Peron government paid too much for those assets (Lewis, 1990). Also, those assets purchased did not make profits and frequently needed government subsidies, which increased the Argentina government's fiscal burden. To strengthen his power base, Peron encouraged the development of labor unions. The encouragement of labor unions did not encourage domestic private investment. Even when the private sector invested, the focus was on profitable short-term projects. For Argentina's long-run growth, it would be better for the government to promote heavy industries (Lewis, 1990). This did not happen under Peron because light industries were developed to create jobs to please voters.

The Oil Crises in the 1970s can be used to illustrate the importance of the distribution of political power between state and society on a country's choices and economic performance. At that time, both South Korea and Argentina imported oil. The quadruple increase in the price of oil in the 1970s increased the costs of importing oil for both countries dramatically. The Argentinean government did not have the capacity to control spending in a deeply divided society and hoped that the increase in the price of oil would be temporary, thus borrowed heavily in the international market. Interest rates for borrowing money at that time were low. In the 1980s, the Federal Reserve Bank of the United States tried to fight inflation by increasing interest rates. As a "small" country in the international financial market, Argentina was a price taker and could not control interest rates. With accumulated debt and much higher interest rates, Argentina could not serve foreign debts and experienced a debt crisis. South Korea also borrowed in international market. However, with strong political power, the South Korea government could take stringent measures to reduce the consumption of oil. For example, the government prohibited government officials from using cars for travels shorter than two kilometers. Also, South Korea took various measures to increase export, and workers were trained to provide construction services in the Middle East. As a result, South Korea's exports of goods and services multiplied. 
Land reforms always face strong oppositions (Huntington, 1968). Why was the land reform in South Korea successful while in Argentina not successful? External factors affected the success of land reform in South Korea. To fight the expansion of communism, the United States supported land reform in South Korea. In Argentina, large land owners opposed land reform and there was no external pressure to engage in land reform. The government has not implemented a successful land reform so far.

\section{Development of manufacturing and technological capabilities in China}

Before the death of Chairman Mao Zedong in 1976, the stage of import substitution prepared China for a comprehensive industry system and improved technological capabilities. At that time, China tried to achieve capital accumulation through low prices of agricultural goods and low wages for workers. Influenced by the success of the four Asian tigers, China began to open to the outside world in 1978. China's reform after 1978 was associated with the practice of dual-track price liberalization, the rise of township and village enterprises, and the opening to international trade (Qian, 2003). With the dual-track price liberalization and the rise of town-village enterprises, state-owned enterprises faced more competition. With the opening of international trade, domestic firms faced more competition (Zhou, 2011). While the political system is centralized, China allows regional experimentations and regional competition (Xu, 2011; Wen, 2016). With more competition after reform, the incentives for firms to adopt modern technologies increased. During the reform period, China imported many technologies from Western countries instead of from the Soviet Union. For example, in year 2001, China signed 3,900 contracts and paid 4.395 billion dollars for importing technologies. In year 2013, China signed 12,448 contracts and paid 41.09 billion dollars for importing technologies (Source: Report on FDI in China 2016, p. 46, Ministry of Commerce of PRC).

Development of technological capabilities in China is heavily influenced by government policies. In terms of policy making on science and technology (S\&T) in China, the National People's Congress establishes laws. The Ministry of Science and Technology (MOST) is a principal player of S\&T policy. MOST works together with other ministries, such as the National Development and Reform Commission. Overall, the China Communist Party has final say in innovation policymaking. The establishment of the leading group at the State Council level institutionalizes coordination among ministries. The government has various policy tools to 
enhance R\&D, such as the direct earmarks scheme, special loans scheme, and the tax credits scheme. Tax Credits are often provided to high-tech enterprises that are newly established in S\&T parks or high-tech zones. After China joined the World Trade Organization, one policy used is national procurement. ${ }^{13}$ Initially, China's policies on S\&T were narrow, mainly industrial policy. Then policies become more comprehensive since other policies such as procurement policy and R\&D subsidies, and industry standards are used. That is, there is a movement from an uncoordinated, piecemeal style of policy making to a coordinated whole-of-government approach (OECD, 2008). The higher degree of coordination of policies can be seen from some mega projects, such as the high-speed rail project discussed below.

The Chinese government began to establish technology parks in 1990s to expedite technology adoption and diffusion under the Torch Program. Technology parks have incubators and other facilities, such as law firms. One science and technology park is Zhongguancun in Beijing established in 1988, with top universities (such as Tsinghua University) and research institutions around. In year 2015, the output of 146 national parks in China produced is more than 8 trillion yuan, which is about $12 \%$ of China's GDP. Those parks pay taxes of 1.4 trillion yuan, which is $11.4 \%$ of China's total tax revenue. The amount of high-tech exports is 241.1 billion dollars, which is $36.8 \%$ of China's high-tech export (Source: MOST of PRC).

Following United States practice, China tries to build world-class research universities. In year 2015, Chinese universities' national share of R\&D personal is $9.4 \%$, the R\&D spending in Chinese universities is 99.86 billion yuan, 39.1 billion is spent on basic research $(54.6 \%$ of China's total spending on basic research) (Source: MOST of PRC). When universities faced strong financial pressures and outside firms did not have absorptive capacities of research generated by universities, Chinese universities began to run firms. Some of the firms such as Tsinghua Holding are very big with assets of billions of dollars. With the existence of asymmetric information in the market for technology, the market may not function well and there is room for university-run firms. Universities may also have played the role of venture capitals in developing technologies. However, in most countries, it is healthy to have universities and industries separated. ${ }^{14}$ With the

\footnotetext{
${ }^{13}$ National procurement policy is used by many developed countries. When Latin American countries privatized firms in the 1990s, innovation capacity of universities were harmed when they lost procurement contracts.

${ }^{14}$ While some university run firms are successful, there are various problems with firms spun off from universities. First, property rights of firms may not be well defined. Second, managing firms are distractive to university administrators and universities may be busy in real estate development (Chen and Kenney, 2007). Universities are supposed to conduct research and enterprises focus on invention. Research and invention are two different things and
} 
development of venture capital in China and other channels to facilitate interaction between universities and firms established, universities may want to spin off their firms, especially after firms grow to large scales.

With improvements in technological capabilities in various manufacturing sectors, China has established strong competitive advantage in various industries. First, China's textile industry produces about half of world output and one-third of world export. According to the World Trade Organization (World Trade Statistical Review 2017, pp. 34-35), China exported 267 billion dollars of textiles and clothing in year 2016.

Second, steel is an important input for sectors such as construction, ship-building, and automobile. With its long input chains, the steel industry is believed to be a strategic sector by the Chinese government. The government's zest for this industry can be seen from the "Great Leap Forward" movement in 1958 which caused millions of deaths. Even after this tragedy, China experienced two rounds of huge fluctuations in the production of steel in the 1960s. Adopting Japanese technologies, Baoshan Iron and Steel Company was built at the end of 1970s. This started Chinese steel firms' adoption of modern technologies. In year 2016, China is the largest producer, consumer, and exporter of steel in the world. China produces about half of the world crude steel and consumes about one third. One interesting observation is that China's production of crude steel in 2015 was 803.8 million tons (World Steel Association: Steel Statistical Yearbook 2016). In the history of the production of steel, no other country has produced more than 200 million tons a year. According to World Trade Statistical Review 2017 (p. 32), China exported 56 billion dollars of iron and steel in year 2016.

Third, China has established some high-technology industries. For example, based on imported technologies from Canada, France, German, and Japan around 2004, China developed indigenous technologies for the high-speed rail (HSR) industry and currently China has more than half of the total mileages of high-speed train of the world. With efforts from dozens of institutions all over the country, this is an example of successful cooperation among industry, academia, and research. Chinese government can coordinate parties and resources because China's HSR industry

require different skill sets. For researchers, they need to publish their research at academic journals. For inventors, they want to keep their business secrets and do not want to publish. Thus, there is a conflict between being a researcher and an inventor. It will be difficult to get research results and commercialize them in a brief period such as three years. Researchers under evaluation pressures may focus on minor modifications rather than significant innovations (Li, 2014). 
is dominated by only a few large SOEs and research institutes. The Ministry of Railways (MOR) coordinated the development of "China Star", with the participation of universities and research institutions such as Southwest Jiaotong University, Central South University, Zhuzhou Electric Locomotive Research Institute, China Academy of Railway Sciences, Sifang Rolling Stock Research Institute, and Qishuyan Locomotive and Rolling Stock Technology Research Institute, firms such as Zhuzhou Electric Locomotive Works, Datong Locomotive Works, CNR Changchun Railway Vehicles (CRV), and CSR Sifang Locomotive Works (Sun, 2015). In 2001, "China Star" went through trial running and experienced overhearing. Thus, MOR started up a series of technology imports and train set purchases from several foreign countries between 2004 and 2007. National Science Foundation of China sponsored 55 HSR-related R\&D projects from 2008 to 2010. MOR and MOST coordinated 11 research institutes, 25 universities, 51 national laboratories and engineering research centers, and 2 SOEs and their subsidiaries to participate in producing new trains. CRH380A, developed in China, has state-of-the art technologies (Sun, 2015). Liu, Lv, and Huang (2016) argue that easy collection of land and government finance also contributed to the success of development of high-speed rail. Also, China is the largest market for robotics and production of robotics in China is increasing rapidly. In year 2016, China produced 72,426 industry robots, an increase of $30.4 \%$ over the previous year (Source: National Bureau of Statistics of PRC).

Table 3 shows that employment in China's manufacturing sector increased over time and the number of patent applications increased rapidly in the last twenty years.

Table 3: Employment and patent applications in China

\begin{tabular}{|l|l|l|l|}
\hline Year & $\begin{array}{l}\% \text { employment in } \\
\text { agriculture }\end{array}$ & $\begin{array}{l}\% \text { employment in } \\
\text { manufacturing }\end{array}$ & $\begin{array}{l}\text { Number of patent } \\
\text { applications }\end{array}$ \\
\hline 1996 & 50.5 & 23.5 & 68,195 \\
\hline 2005 & 44.8 & 23.8 & 287,162 \\
\hline 2015 & 28.3 & 29.3 & $2,242,370$ \\
\hline
\end{tabular}

Source: National Bureau of Statistics of PRC, http://data.stats.gov.cn/easyquery.htm? cn=C01

China's economic performance is affected by the presence of a strong government in China, which is a result of historical factors. Geographical conditions helped the unification of China. The power of the central government in ancient China was helped by the adoption of the 
county system and the Imperial Examination System (Zhou, 2018). First, while feudalism gradually disappeared in Europe in the Middle Ages, China adopted the county system in the Qin Dynasty more than two thousand years ago, much earlier than Europe. Compared with feudalism, the county system led to the concentration of power in the central government. Second, the Imperial Examination System was adopted in the Sui Dynasty (581-618) to select government officials. ${ }^{15}$ Under the Imperial Examination System, the power to select officials was centralized in the central government. Positions up to the prime minister level were open to almost everyone. According to the study of $\mathrm{He}$ (1962), the Imperial Examination System was extremely competitive. No family could keep being competitive for several successive generations. ${ }^{16}$ Thus, high-rank officials were continuously reshuffled and social mobility was high. This system helped the concentration of power in the central government. Because there was no stable noble class to challenge the emperors in China, the Ming and Qing Dynasties could rule effectively for hundreds of years.

Land reform in the 1950s in China mainland was more abrupt than land reforms in Japan, South Korea, and Taiwan in the sense that many large landlords were physically eliminated. Land in China is officially owned by the state. Labor unions are suppressed in China. Without intense competition from other groups such as large landlords or labor unions, the Chinese government is strong and is capable in implementing policies. ${ }^{17}$

\section{Will China avoid the middle-income trap?}

Currently China is an upper middle-income country. With the increasing wage rates, the comparative advantage in labor-intensive goods is gone (Zhang, Yang, and Wang, 2011). China needs to switch from factor based to efficiency or innovation based growth and Chinese government and firms need to continuously rationalize their behaviors to be more efficient. Other things equal, better technologies will reduce the demand for natural resources. By relying on

\footnotetext{
${ }^{15}$ Before this adoption, the Nine-Rank System was used to select government officials. Under this system, candidates were classified into nine grades by local officials and the power to select officials was thus localized. Initially this system played a useful role in consolidating the elite's support for the government, but it was eventually controlled by powerful clans. Later, family background became the dominant factor in determining an individual's ranking. Thus, individuals from influential families dominated high ranks and individuals from less influential families rarely got high ranks. With the building-up of power by clans over generations, the power struggle among government and powerful clans led to frequent overthrows of governments during the South-North Dynasties.

${ }^{16}$ The practice of sharing property among all sons in ancient China decreased the possibility of the concentration of land ownership and thus the possibility of relying on land property as an independent source of political power.

${ }^{17}$ A strong government also is vulnerable in making huge mistakes (Trebilcock, 1981).
} 
technological advances and creating equal opportunities for everyone, economic growth in China will benefit not only Chinese, but also the rest of the world. Will China keep on growing? There are some concerns with China's manufacturing sector, strengthening of technological capabilities, and social and income equalities for sustained growth.

First, the manufacturing sector faces challenges from rising costs and diversions of resources. While small and medium-sized manufacturing firms help in easing income distribution concentration and play important roles in innovations, they face increasing costs. Various stateowned enterprises (SOEs) occupied in resources, infrastructure, and financial sectors in China have high degrees of monopoly power and their monopoly power inflates the prices paid by small and medium-sized firms for inputs. SOEs have access to low-cost bank loans. As powerful interest groups, they have significant influences on China's policies. To develop small and medium-sized firms, it is important to reduce the fees and charges and give them access to low-cost loans. Also, while the tax reform in 1993 increased the share of tax revenues going to the central government, local governments began to rely on real estate development for revenue. High returns in the real estate sector cause resources moving out of the manufacturing sector.

Second, it is frequently stated that China's manufacturing sector is big, but not strong. For example, while China produces more than 20 million cars a year, indigenous firms are mainly serving low ends of the market. China's automobile industry is dominated by foreign firms monopolizing technologies ( $\mathrm{Lu}$ and Feng, 2005). For Chinese firms to become strong, technological capabilities of domestic firms need to be improved. Currently China's exports (especially high-tech exports) are dominated by foreign firms. In year 2015, 44.13\% of China's exports is conducted by foreign firms or joint ventures (source: Statistics on FDI in China, 2016, Ministry of Commerce of the PRC). In year 2013, more than 70\% of high technology exports of China comes from foreign firms or joint ventures (source: Report on FDI in China 2016, p. 47, Ministry of Commerce of PRC). While multinational firm do conduct some kinds of research and development $(R \& D)$ in developing countries, those kinds of $R \& D$ are less likely to be fundamental research and more likely to be applied to adjust to local market conditions. Using Latin America as an example, Amsden (2009) has argued that local firms are more active in conducting R\&D than multinational firms. ${ }^{18}$ In their survey of empirical research on various countries, Harrison and Rodriguez-Clare (2010) find there are no horizontal spillovers from foreign investments. Fu and

\footnotetext{
${ }^{18}$ Japan and South Korea limited the entry of foreign firms during their take-off periods.
} 
Gong (2011) find that collective indigenous R\&D activities at the industry level are major driver of technology upgrading of indigenous firms in China and R\&D activities of foreign-invested firms have a significant negative impact on the technical change of local firms. Hail and Long (2011) fail to find evidence of systematic positive productivity spillovers from FDI in China. Overall, the development of technological capabilities relies on domestic firms unbundling foreign technologies and developing indigenous technologies.

Third, an equal and fluid society provides the social foundation for sustained growth. In the past four decades, income inequality increased sharply in China. Institutions such as the Hukou system, land ownership, and rural-urban inequality contributed to income inequalities (Islam, 2014). China's Gini coefficient is higher than East Asian economies and inequalities in assets in China are increasing (Lee and Li, 2014). China's income inequality is like or above the levels of Latin American countries. Benefits of economic development should be shared by everyone and high inequality is inconsistent with traditional Chinese thoughts such as Confucianism which advocates an equal-access society. High income inequality can lead to negative consequences. First, in Argentina it might have harmed Argentina's adoption of labor-saving technologies (Francis, 2014). A divided society will make the development of the manufacturing sector more difficult. Second, high inequality can increase social unrest. China's industrialization will benefit and needs the contribution of hundreds of millions of people. To keep on developing technological capabilities, broad participations of citizens in terms of opportunities of getting education, starting firms, and fair competition are needed.

There are positive signs of China's sustained growth. First, China has developed significant comparative advantage in exporting manufactured goods. Driven by skill and technology improvements, China's exports have become increasingly sophisticated (Upward, Wang, and Zheng, 2013). Second, recognizing the importance of innovation for China's future growth, the Chinese government has a high interest in encouraging innovation in China. Under the "National Medium and Long-Term Program for Scientific and Technological Development (2006-2020)" in 2006, the Chinese government has emphasized the development of indigenous technological capabilities. Under this plan, firms will be the main player of this system. The Plan calls more coordination among players of the national innovation system. Some of the objectives are as follows. By 2020, 2.5 percent of the GDP should be allocated to R\&D, and $60 \%$ of the source of GDP growth should be based on innovations. Research and development activities rely on 
educated workforce. China has the largest number of college graduates in the world. In year 2015, including web-based, adult, and regular students, about 10 million Chinese got college degrees. ${ }^{19}$ University students are encouraged to engage in innovations. In year 2016, China spent 1550 billion yuan (which is $2.08 \%$ of GDP) on research and development (Source: National Bureau of Statistics of PRC). There are many innovative firms in China, such as Huawei. Universities such as Tsinghua are first-class in the world in engineering. A country's innovation system consists of $\mathrm{R} \& \mathrm{D}$, implementation, end-use, education, and linkage. The degree of coordination of various parts of China's innovation system is increasing. Wei, Xie, and Zhang (2017) have conducted systematic evaluation on innovation capacities in China. They show that the numbers of patent applications from China are high and the qualities of Chinese patents are comparable with those from other countries. Finally, the Chinese government is taking measures to reduce income inequality, such as relaxing the Hukou system and the provision of pension incomes in rural areas.

\section{Conclusion}

A country's industrialization process is frequently painful. In this paper we have argued that a country's ability to develop technological capabilities in the manufacturing sector is important in avoiding the middle-income trap. While Argentina became a middle-income country through the development of the agricultural sector and has not avoided the middle-income trap, South Korea became a middle-income country through the development of the manufacturing sector and has avoided the middle-income trap. With the adoption of the Imperial Examination System, historical China was a fluid society with opportunities to become highest-rank officials opening to almost everyone. China became a middle-income also through the development of the manufacturing sector. With the building of an equal-access society and development of technological capabilities, China will avoid the middle-income trap.

The reasoning in this paper can also be used to address development experiences of other countries, such as Brazil, Mexico, Philippines, and Thailand. Land distribution in Brazil is quite uneven and income inequality is high. Leadership was strong only at the early time of the military regime. Overall Brazil did not have a high concentration of political power in the government. The diverse distribution of power had consequences. First, like South Korea, Brazil also tried to

\footnotetext{
${ }^{19}$ Source: Ministry of education of PRC, http://www.moe.gov.cn/s78/A03/moe_560/jytjsj_2015/2015_qg/201610/t20161011_284371.html
} 
develop the steel industry. State firms played heavy roles in this process. However, one significant difference between South Korea and Brazil is that Brazil relied heavily on FDI of multinational firms, while Korea discouraged FDI. Multinational firms might be less interested in developing local research and development facilities. Second, during the period of import substitution, to create more employment, Brazil was not selective in industries. Third, competing for a share of the economy made the adjustment after oil shocks difficult. After the oil shock, the government chose to borrow to keep the high growth rate in the previous period. The debt burden became a vicious circle (Baer, 2001).

In Mexico, land reform in the Porfirio Diaz period was not successful. While one party (Institutional Revolutionary Party, or PRI) ruled Mexico for more than seven decades until 2000, we may think that the degree of the concentration of power in Mexico was high. However, the one-party system was achieved through coopting by absorbing potential political opponents into the party, and the distribution of political power in Mexico was diverse. Presidents of PRI tried to achieve unanimity in decision making, and this made the handling of economic issues difficult (Vernon, 1963). To increase the power of the government, presidents tried to establish many political organizations so that the dependence on one specific group would be small. Mexico was quite divided in many issues, such as the attitude toward the Catholic Church (Miller, 1985). Mexico was an oil exporter in the 1970s, and the high price of oil was good news. However, higher oil revenues led to even higher government spending on oil exploration activities and other projects. This kind of high spending was based on the expectation that the price of oil would be high in the 1980s. When the price of oil decreased in the 1980s, Mexico had a debt crisis. For Latin American countries, a country may have foreign debt crises regardless of whether this country is exporting oil (Mexico) or importing oil (Argentina). Overall oil shocks may not be the reason leading to debt crises, the state could not impose disciplines on society and spending is the reason leading to debt crises.

Economic growth in Philippines leaves much to desire. While per capita GDP of Philippines was higher than that in South Korea in the 1950s, now it is much lower than that in South Korea. Before being colonized by Spain, Philippines was composed of small kingdoms and did not have a central government. Philippines is divided in terms of ethnic groups. While there were various attempts, Philippines has not implemented a successful land reform so far. For example, the one after World War II could not succeed because General Douglas MacArthur was 
too close to the elite in Philippines (Francia, 2010). While Philippines is in Asia, as a former colony of Spain for more than three hundred years, most of the population is Catholic. The political structure is oligarchy. Those aspects make Philippines similar to Latin American rather than to East Asian countries. With corruption prevalent, rent seeking is more profitable than developing innovative technologies. Philippines has not developed strong technological capabilities and has not demonstrated the ability to move beyond the middle-income trap.

Thailand has been a middle-level income country for decades. Thailand is world's largest exporter of rice, an agricultural good. Output increases in the agricultural sector relied on expansions of the amounts of land used, rather than increases in agricultural productivities (Siriprachai, 2012). Overall, Thailand has not developed strong technological capabilities to avoid the middle-income trap. This is related to the observation that Thailand did not have coherent

policies of development. During the period of import substitution, the government was more interested in tariff revenues rather than developing technological capabilities through linkages among industries. With the boom and bust in the 1990s, there was a divide of interests between rural areas and cities (Phongpaichit and Baker, 1998). Political power is dispersed among the king, military, politicians, technocrats, and other forces. While military coups are frequently seen in Thailand, Siriprachai (2012) has argued that the military in Thailand may not be a coherent group even under military rule. With limited abilities to collect taxes, the government is weak and capability to promote technological development has not been sufficiently demonstrated.

\section{References}

Adler, Emanuel. 1987. The Power of Ideology: The Quest for Technological Autonomy in Argentina and Brazil. Berkeley, CA: University of California Press.

Aiyar, Shekhar, Romain Duval, Damien Puy, Yiqun Wu, and Longmei Zhang. 2013. Growth slowdowns and the middle-income trap. IMF Working Paper.

Amsden, Alice. 1989. Asia's Next Giant: South Korea and Late Industrialization. New York, NY: Oxford University Press. 
Amsden, Alice. 2009. Nationality of firm ownership in developing countries: who should 'crowd out' whom in imperfect markets? in Industrial Policy and Development: The Political Economy of Capabilities Accumulation, edited by Cimoli, Mario, Giovanni Dosi, and Joseph Stiglitz. New York: Oxford University Press.

Baer, Werner. 2001. The Brazilian Economy: Growth and Development. Westport, CT: Praeger Publishers.

Beckert, Sven. 2014. Empire of Cotton: A Global History. New York, NY: Vintage Books.

Black, Cyril, et al. 1975. The Modernization of Japan and Russia. New York, NY: The Free Press.

Brown, Jonathan. 2011. A Brief History of Argentina. $2^{\text {nd }}$ edition, New York: Checkmark Books.

Cai, Fang. 2012. Is there a "middle-income trap"? Theories, experiences and relevance to China. China \& World Economy 20, 49-61.

Chang, Ha-Joon. 2003. Kicking Away the Ladder: Development Strategy in Historical Perspective. London, UK: Anthem Press.

Chen, Kun, and Martin Kenney. 2007. Universities/Research Institutes and Regional Innovation Systems: The Cases of Beijing and Shenzhen. World Development 35, 1056-1074.

Chu, Wan-Wen. 2011. How the Chinese government promoted a global automobile industry. Industrial and Corporate Change 20, 1235-1276.

Deyo, Frederic. 1989. Beneath the Miracle: Labor Subordination in the New Asian Industrialism. Oakland, CA: University of California Press.

Eichengreen, Barry, Donghyun Park, and Kwanho Shin. 2014. Growth slowdowns redux. Japan and the World Economy 32, 65-84. 
Francia, Luis. 2010. A History of the Philippines: From Indios Bravos to Filipinos. New York, NY: Overlook Press.

Francis, Joseph. 2014. The Terms of Trade and the Rise of Argentina in the Long Nineteenth Century. Ph. D. Dissertation, London School of Economics and Political Science.

Frankel, Francine. 2005. India's Political Economy: 1947-2004. New York, NY: Oxford University Press.

Fu, Xiaolan, and Yundan Gong. 2011. Indigenous and foreign innovation efforts and drivers of technological upgrading: evidence from China. World Development 39, 1213-1225.

Geddes, Barbara. 1994. Politician's Dilemma: Building State Capacity in Latin America. Oakland, CA: University of California Press.

Gao, Yanyan, Zhibiao Liu, Shunfeng Song, and Jianghuai Zheng. 2013. Technological capacity, product position, and firm competitiveness: an empirical analysis. The Chinese Economy 46, 5574.

Hail, Galina, and Cheryl Long. 2011. Are there productivity spillovers from foreign direct investment in China? Pacific Economic Review 16, 135-153.

Harrison, Ann, and Andres Rodriguez-Clare. 2010. Trade, foreign investment, and industrial policy for developing countries. in Dani Rodrik and Mark Rosenzweig, (eds.) Handbook of Development Economics, Vol. 5, Amsterdam: North-Holland, pp. 4039-4214.

He, Bingdi. 1962. The Ladder of Success in Imperial China, Aspects of Social Mobility, 13681911. New York, NY: Columbia University Press. 
Hong, Wontak. 1980. Export promotion and employment growth in South Korea. in Anne O. Krueger, Hal B. Lary, Terry Monson, and Narongchai Akrasanee, eds. Trade and Employment in Developing Countries, Volume 1: Individual Studies. University of Chicago Press, pp. 341 - 392. Huntington, Samuel. 1968. Political Order in Changing Societies. New Haven, CT: Yale University Press.

Islam, Nazrul. 2014. Will inequality lead China to the middle income trap? Frontiers of Economics in China 9, 398-437.

Johnson, Chalmers. 1982. MITI and the Japanese Miracle: The Growth of Industrial Policy, 19251975. Stanford, CA: Stanford University Press.

Ju, Min, Hung-Gay Fung, and Haim Mano. 2013. Firm capabilities and performance: Institutional perspective on foreign and local firms in China. The Chinese Economy 46, 86-104.

Lee, Keun, and Shi Li. 2014. Possibility of a middle income trap in China: assessment in terms of the literature on innovation, big business, and inequality. Frontiers of Economics in China 9, 370397.

Lewis, Paul. 1990. The Crisis of Argentine Capitalism. Chapel Hill, NC: University of North Carolina Press.

Li, Kai. 2014. Thoughts on encouraging innovation in China's high-technology research. Communications of the China Computer Federation 10(6), 10-16.

Lin, Justin Yifu. 2012. New Structural Economics: A Framework for Rethinking Development and Policy. Washington, DC: The World Bank.

Lin, Justin Yifu. 2017. Industrial policies for avoiding the middle-income trap: a new structural economics perspective. Journal of Chinese Economic and Business studies 15, 5-18. 
List, Frederick. 1856. The National System of Political Economy. Philadelphia, PA: J. B. Lippincott \& Co.

Liu, Rongfang, Liu Lv, and Zhaodong Huang. 2016. High speed rail development in China: A case study of state-guided technology transfer. In Zhou, Yu, William Lazonick, Yifei Sun (eds) China as an Innovation Nation. Oxford: Oxford University Press, pp. 165-191.

Lockwood, William. 1968. The Economic Development of Japan: Growth and Structural Change. Princeton, NJ: Princeton University Press.

Lu, Feng, and Kaidong Feng. 2005. FaZhan WoGuo ZiZhu ZhiShi ChanQuan QiChe GongYe De ZhengCe XuanZe (The Strategic Choice to Develop the Chinese Automobile Industry with Indigenous IPRs). Beijing: Peking University Press.

Malechi, Edward. 1991. Technology and Economic Development: The Dynamics of Local, Regional, and National Competitiveness. New York, NY: Longman.

Migdal, Joel. 1988. Strong Societies and Weak States: State-Society Relations and State Capabilities in the Third World. Princeton, NJ: Princeton University Press.

Miller, Robert Ryal. 1985. Mexico: A History. Norman, OK: University of Oklahoma Press.

Myrdal, Gunnar. 1968. Asian Drama: An Inquiry into the Poverty of Nations. New York, NY: Pantheon.

OECD. 2008. OECD Reviews of Innovation Policy: China. OECD Publishing.

Olson, Mancur. 1982. The Rise and Decline of Nations. New Haven, CT: Yale University Press.

Otsuka, Keijiro, Gustav Ranis, and Gary Saxonhouse. 1988. Comparative Technology Choice in Development. New York, NY: St. Martin's Press. 
Phongpaichit, Pasuk, and Chris Baker. 1998. Thailand's Boom and Bust. Chiang Mai, Thailand: Silkworm Books.

Qian, Yingyi. 2003. "How reform worked in China," in In Search of Prosperity: Analytic Narratives on Economic Growth, edited by Dani Rodrik, Princeton, NJ: Princeton University Press, pp. 297-333.

Rhee, Yung Whee, Bruce Ross-Larson, and Garry Pursell. 1984. Korea's Competitive Edge: Managing the Entry into World Markets. Baltimore, MD: Johns Hopkins University Press.

Rock, David. 1985. Argentina 1516-1987: From Spanish Colonization to Alfonsin Argentina. Berkeley, CA: University of California Berkeley Press.

Siriprachai, Somboon. 2012. Industrialization with a Weak State: Thailand's Development in Historical Perspective. Singapore: National University of Singapore Press.

Sun, Zhe. 2015. Technology innovation and entrepreneurial state: the development of China's high-speed rail industry, Technology Analysis \& Strategic Management 27, 646-659.

Trebilcock, Clive. 1981. The Industrialization of the Continental Powers 1780-1914. New York: Longman.

Upward, Richard, Zheng Wang, and Jinghai Zheng. 2013. Weighing China's export basket: The domestic content and technology intensity of Chinese exports. Journal of Comparative Economics $41,527-543$.

Vernon, Raymond. 1963. The Dilemma of Mexican's Development. Cambridge, MA: Harvard University Press. 
Wade, Robert. 2004. Governing the Market: Economic Theory and the Role of Government in East Asian Industrialization. Revised edition, Princeton, NJ: Princeton University Press.

Wei, Shang-Jin, Zhuan Xie, and Xiaobo Zhang. 2017. From "Made in China" to Innovated in China": Necessity, prospect, and challenges. Journal of Economic Perspectives 31, 49-70.

Wen. Yi. 2016. The Making of an Economic Superpower: Unlocking China's Secret of Rapid Industrialization. Singapore: World Scientific Publishing Company.

World Bank. 2010. East Asia and Pacific Economic Update 2010, Volume 2: Robust Recovery, Rising Risks. Washington, DC: The World Bank.

Wu, Yanrui. 2014. Productivity, economic growth and the middle income trap: implications for China. Frontiers of Economics in China 9, 460-483.

$\mathrm{Xu}$, Chenggang. 2011. The fundamental institutions of China's reforms and development. Journal of Economic Literature 49, 1076-1151.

Yoshida, Shigeru. 1967. Japan's Decisive Century, 1867-1967. Westport, CT: Praeger Publishers.

Zhang, Xiaobo, Jin Yang, and Shenglin Wang. 2011. China has reached the Lewis turning point. China Economic Review 22, 542-554.

Zhou, Haiwen. 2011. Economic systems and economic growth. Atlantic Economic Journal 39, 217-229.

Zhou, Haiwen. 2018. A model of institutional complementarities in ancient China. Eastern Economic Journal. 